\title{
Involvement of Seladin-1 in goniothalamin- induced apoptosis in urinary bladder cancer cells
}

\author{
Heng Kai Yen ${ }^{1,5}$, Afifah-Radiah Fauzi ${ }^{1}$, Laily Bin Din², Valerie J McKelvey-Martin ${ }^{3}$, Chan Kok Meng ${ }^{4,5}$, \\ Salmaan Hussain Inayat-Hussain ${ }^{4,5}$ and Nor Fadilah Rajab $b^{1,5^{*}}$
}

\begin{abstract}
Background: Selective Alzheimer Disease Indicator-1 (or Seladin-1) is a multifunctional protein first discovered by downregulation of its expression in Alzheimer's disease. Interestingly, the expression of this protein is upregulated in several cancers, including primary bladder cancer. However, its role in cancer formation has yet to be discovered. Goniothalamin is a natural product that has been demonstrated to induce apoptosis in various cancer cell lines. In this study, we have elucidated the role of Seladin-1 in goniothalamin-induced cytotoxicity towards human urinary bladder cancer cell line RT4.
\end{abstract}

Methods: The cytotoxicity of goniothalamin in human urinary bladder cancer cell line RT4 was assessed using MTT assay and the mode of cell death was determined by Annexin V-FITC/PI labeling assay. Finally, the expression of Seladin-1 protein in goniothalamin-treated RT4 cells was determined by Western blot.

Results: MTT assay showed that the cytotoxicity of goniothalamin on RT4 cells was concentration and time dependent with $\mathrm{IC}_{50}$ values of $61 \mu \mathrm{M}(24 \mathrm{hr}$ ), $38 \mu \mathrm{M}$ (48 hr) and $31 \mu \mathrm{M}$ for $72 \mathrm{hr}$, respectively. Cell death induced was confirmed through apoptosis; as assessed using the Annexin V-FITC/PI labeling assay. Furthermore, the involvement of Seladin-1 in goniothalamin-induced apoptosis was evidenced through the cleavage of $60 \mathrm{kDa}$ protein to $40 \mathrm{kDa}$ and $20 \mathrm{kDa}$. This was followed by a gradual increase of $20 \mathrm{kDa}$ fragment suggesting the involvement of Seladin-1 in goniothalamin-induced apoptosis on RT4 cells.

Conclusion: This study demonstrates that goniothalamin induce cytotoxicity and apoptosis on RT4 cells. The involvement of Seladin-1 in goniothalamin-induced apoptosis further suggested that Seladin-1 may play a role in the formation of primary bladder cancer.

Keywords: Seladin-1, Bladder cancer, Goniothalamin, Apoptosis

\section{Background}

The urinary bladder functions as a temporary storage for urine before being excreted out from the body. It is composed of layers of transitional epithelium; including smooth muscle, which allows the organ to expand and contract [1]. It is an organ highly prone to cancer of genitourinary system, with $90 \%$ of the cancer being transitional cell carcinoma, whilst the rest are squamous and

\footnotetext{
* Correspondence: nfadilah@medic.ukm.my

1 Biomedical Science Programme, Faculty of Health Sciences, Universiti Kebangsaan Malaysia, Jalan Raja Muda Abdul Aziz, 50300 Kuala Lumpur, Malaysia

${ }^{5}$ Toxicology Laboratory, Faculty of Health Sciences, Universiti Kebangsaan Malaysia, Jalan Raja Muda Abdul Aziz, 50300 Kuala Lumpur, Malaysia Full list of author information is available at the end of the article
}

adenocarcinoma [2]. The etiology of urinary bladder cancer include tobacco smoking, occupational exposure to chemical carcinogens, such as aromatic amine and Schistosomal infections $[3,4]$. The progression of cancer is a multistep process that includes genetic alteration; as the deregulation (or mutation) of certain genes may predispose to certain cancers. According to Doherty and coworkers, different gene expressions that were found at two anatomical areas (ureteric orifice and dome) of normal bladders are commonly prone to have primary bladder cancer. The expressions of these genes may give some insight into bladder carcinogenesis; especially Seladin-1, which was found upregulated at the ureteric 
orifice. However, little is known about this gene on its involvement especially in cancers [5-7].

Selective Alzheimer's disease Indicator 1 (or Seladin-1) was first discovered in Alzheimer's disease. This gene has an anti-apoptotic function in brain tissue, whereby its downregulation has been associated with neurodegeneration [8]. Seladin-1 was found to be identical to the gene DHCR24, which functions as a key enzyme in cholesterol biosynthesis and lipid raft formation $[9,10]$. It was also described as a multifunctional protein. In cancer, Seladin-1 was found highly expressed in adrenal cancer, pituitary tumors, urinary bladder cancer, melanoma, and prostate cancer [7,11-14]. The high expression of Seladin-1 found in those cancers may have been due to high cholesterol content; however, the significance of Seladin-1 in cancer was not fully elucidated. From previously reported literature, we strongly believe in the involvement of Seladin-1 in carcinogenesis. It has also been shown that Seladin-1 was cleaved by caspase6 and caspase- 3 , which proved Seladin-1 act as a death substrate for caspases and may function as pro-apoptotic element upon cleavage [8]. According to previous studies, upon oncogenic induction and oxidative stress, Seladin-1 was found to bind p53 and displace mdm-2 resulted in the accumulation of active p53. This interaction suggests a role of Seladin-1 in the regulation of cell fate [15]. In addition, Seladin-1 was demonstrated as lipopolysaccharide (LPS) responsive gene product that regulates anti-inflammatory response [16].

Goniothalamin is a natural product isolated from Goniothalamus species, which is abundantly found in Malaysia. This styryl lactone derivative possesses potent cytotoxic activity and induces apoptosis in various cancer cell lines; such as liver, breast, kidney, ovarian and leukemic cell lines [17-23]. Recent studies have demonstrated the anti-inflammatory and antiproliferative effect of goniothamin in vivo to further confirm the potential of goniothalamin and its related molecules as a therapeutic agent [24]. The mechanism of goniothalamin-induced apoptosis was found involves oxidative stress and mitochondria mediated pathway $[17,25]$. Previous studies have shown that goniothalamin induces DNA damage, generation of reactive oxygen species (ROS), loss of mitochondria membrane potential, release of cytochrome c and activation of caspases [17,18,21,22,25]. Goniothalamin-induced apoptosis mainly via intrinsic pathway; however, the full mechanism is yet to be elucidated. Thus, in this study, the cytotoxicity of goniothalamin was assessed using MTT assay in urinary bladder cancer cell line RT4 and etoposide, a known cytotoxic agent was used as a positive control. The determination of apoptosis event and the involvement of Seladin-1 in goniothalamin-induced apoptosis were also elucidated, to further understand the underlying mechanism.

\section{Methods}

\section{Goniothalamin}

The compound goniothalamin was provided by Professor Dato Dr. Laily Bin Din from Universiti Kebangsaan Malaysia (Bangi). It was isolated from G. andersonii as described previously [17,26], a stock solution of $50 \mathrm{mM}$ goniothalamin was prepared by dissolving in DMSO (Ajax Finechem) with the final concentration less than $1 \%$.

\section{Cell line $\&$ reagents}

Urinary bladder cancer cell lines RT4 was obtained from ATCC and cultured in McCoy's 5A medium (Gibco) supplemented with $10 \%$ fetal bovine serum and $1 \%$ penicillin/ streptomycin. Cells were subcultured every two days with $0.25 \%$ trypsin/ $1.5 \mathrm{mM}$ EDTA and maintained at $37^{\circ} \mathrm{C}$ under $5 \% \mathrm{CO}_{2}$ environment. The RT4 cells used in this study were within 10 passages.

\section{MTT assay}

The cytotoxicity of goniothalamin on RT4 cells was assessed by MTT assay as described previously [25,27]. RT4 cells were seeded in a 96 well microplate at a concentration of $5 \times 10^{4}$ cells per well and incubated 24 hrs. Next, a fresh medium containing tested compound was added. The concentrations of goniothalamin used were $6.25,12.5,25,50$ and $100 \mu \mathrm{M}$ and etoposide were 18.75 , $37.5,75,150$ and $300 \mu \mathrm{M}$. Cells were treated for 24,48 and $72 \mathrm{hrs}$. After treatment, $20 \mathrm{ul} \mathrm{MTT}(5 \mathrm{mg} / \mathrm{ml})$ was added and further incubated for $4 \mathrm{hrs}$. Supernatant was then discarded and replaced with 200ul DMSO. The microplate was incubated for $15 \mathrm{~m}$ and shaken to dissolve the crystal formazan. The viability of the cells was determined by measuring the absorbance of each well on an ELISA plate reader (Biorad) at $570 \mathrm{~nm}$. The percentage viability of the cells was determined by comparing the mean absorbance of treated cells to untreated cells. A graph was plotted with percentage viability versus concentration of the tested compound and $\mathrm{IC}_{50}$ value was obtained.

\section{Annexin V-FITC/PI labeling assay}

Determinations of the mode of cell death or the apoptosis event induced by the goniothalamin on RT4 cells were assessed by Annexin V-FITC/PI labeling assay, as described previously [25]. RT4 cells were seeded at $1 \times 10^{6}$ cells per well in a six well plate and incubated for $24 \mathrm{hrs}$, followed by treatment of goniothalamin at concentrations of 50, $61\left(\mathrm{IC}_{50}\right)$ and $100 \mu \mathrm{M}$, and treatment of etoposide at $46 \mu \mathrm{M}\left(\mathrm{IC}_{50}\right)$ act as positive control, and incubated for 24hrs. After treatment, cells were harvested. Medium and floaters from each well were collected and cells were rinse with PBS and incubated with trypsin/EDTA until $80 \%$ of the cells were detached. All cell suspensions were collected and centrifuged at $220 \times g$ for 5 mins. Next, the 
supernatant was discarded and the pellets were washed with chilled PBS and centrifuged at $220 \times g$ for 5 mins at $4{ }^{\circ} \mathrm{C}$. Pellets were washed twice and the supernatant was discarded. Next, $150 \mu \mathrm{l}$ of chill Annexin V binding buffer was added, followed by $5 \mu$ of Annexin V-FITC (BD Pharmingen) and incubated for 15 mins. During the final 2 mins, $5 \mu \mathrm{l}$ of propidium iodide $(50 \mu \mathrm{g} / \mathrm{ml})$ was added and further incubated. After staining, $350 \mu \mathrm{l}$ of Annexin V binding buffer was added and all of the samples were transferred to Falcon flow tubes for analysis using FACSCanto Flow Cytometer (BD Bioscience, USA).

\section{Western blotting}

RT4 cells were seeded at a concentration of $2.5 \times 10^{5}$ cells $/ \mathrm{ml}$ on a tissue culture dish and incubated for $24 \mathrm{hrs}$. Next, the cells were treated with goniothalamin at the concentration of $61 \mu \mathrm{M}\left(\mathrm{IC}_{50}\right)$ for $2,4,8,16$, and $24 \mathrm{hrs}$. Following treatment, cell lysates were collected and protein samples were prepared and denatured at $95^{\circ} \mathrm{C}$ for 5 mins. Next, $20 \mu \mathrm{g} / \mathrm{ml}$ lysate was resolved on $12 \%$ SDSpolyacrylamide gel electrophoresis and blotted onto a polyvinylidene fluoride membrane. Western blotting was carried out as described previously [18]. Rabbit monoclonal anti-Seladin-1 antibody (Sigma, USA) was used at a dilution of 1:5000 in 5\% skimmed milk and incubated at $4^{\circ} \mathrm{C}$ overnight. Meanwhile, rabbit monoclonal beta actin antibody (Cell Signaling, USA) was used at a dilution of 1:10000. After incubation of the primary antibody, secondary antibody (goat anti-rabbit HRP conjugated antibody, Cell Signaling, USA) was added and incubated for $1 \mathrm{hr}$. prior to detection by chemiluminenscene (Amersham, UK).

\section{Statistical analysis}

All experiments were repeated three times and data were presented as mean \pm SEM. Statistical analysis was performed using Statistical Package for Social Science (SPSS) version 21 and One Way ANOVA post-hoc technique was used. A $p$ value $<0.05$ was considered statistically significant.

\section{Results \\ MTT assay}

The cytotoxic effect of goniothalamin on RT4 cells was assessed by MTT assay. Following treatment of 24, 48 and $72 \mathrm{hr}$, the percentage viability of the cells was obtained and graph was plotted versus concentration of goniothalamin (see Figure 1). The graph shows that the $\mathrm{IC}_{50}$ value was $61 \mu \mathrm{M}, 38 \mu \mathrm{M}$ and $31 \mu \mathrm{M}$ following $24 \mathrm{hrs}, 48 \mathrm{hrs}$ and 72 hrs treatment, respectively. The viability drop from $100 \%$ from control and further reduced across concentrations of goniothalamin and time points; with the highest concentration $(100 \mu \mathrm{M})$ of goniothalamin showed less than $20 \%$ of cells were viable following $24 \mathrm{hrs}, 48 \mathrm{hrs}$, and $72 \mathrm{hrs}$ of treatment. Statistical analysis showed that there was a significant reduction in the percentage of cell viability following treatment with goniothalamin at each concentration (i.e., $6.25,12.5,25,50$, and $100 \mu \mathrm{M}$ ) compared to control or untreated cells $(p<0.05)$. Etoposide was used as a positive control for this experiment and the results of the cytotoxic effect are shown in Figure 2 . The $\mathrm{IC}_{50}$ value of etoposide on RT4 cells was $46 \mu \mathrm{M}, 15 \mu \mathrm{M}$ and $14 \mu \mathrm{M}$ following $24 \mathrm{hrs}, 48 \mathrm{hrs}$ and $72 \mathrm{hrs}$ treatment, respectively. There was a significant reduction in percent viability compared to the control at each concentration of etoposide $(p<0.05)$.

\section{Annexin V-FITC/PI labeling}

Goniothalamin was known to induce cell death with mainly through apoptosis at various cell lines [17-23]. In this study mode of cell death or determination of apoptosis event induced by goniothalamin on bladder cancer

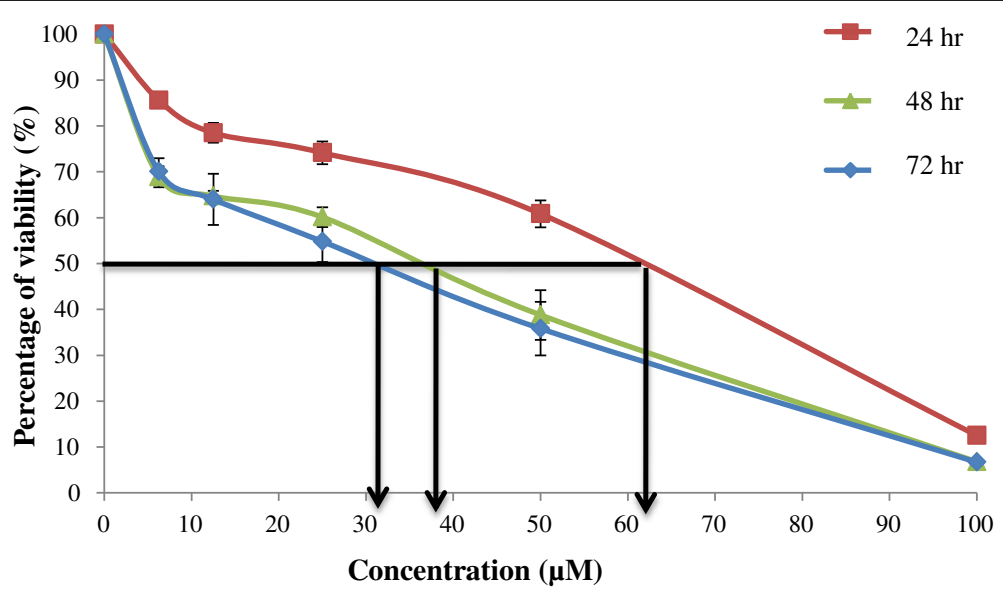

Figure 1 Percentage of viability of RT4 cells treated by goniothalamin $(6.25,12.5,25,50 \& 100 \mu \mathrm{M})$ for $24,48 \& 72 \mathrm{hr}$. Each point represents mean \pm SEM of 3 different experiments ( ${ }^{*} p<0.05$ compare to control). 


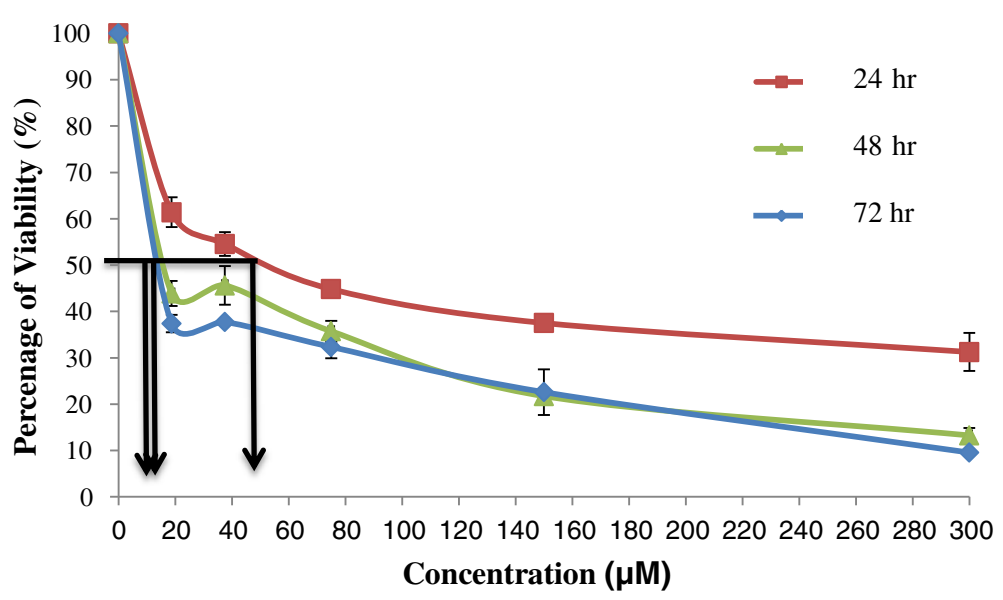

Figure 2 Percentage of viability of RT4 cells treated by etoposide $(18.75,37.5,75,150$, and $300 \mu \mathrm{M})$ for 24,48 , and 72 hrs. Each point represents mean \pm SEM of 3 different experiments ( ${ }^{*} p<0.05$ compared to the control).

cell line RT4 was assessed by using Annexin V-FITC/PI Labeling assay as described previously [25], at the concentration of 50, $61\left(\mathrm{IC}_{50}\right) \& 100 \mu \mathrm{M}$ of goniothalamin following $24 \mathrm{hr}$ treatment. Three concentration of goniothalamin was chosen in order to understand the concentration dependent cell death event induced by goniothalamin. By using Annexin V-FITC/PI staining, apoptosis and necrosis event was quantified by flow cytometry as shown in Figure 3. The cytogram quadrant of annexin $\mathrm{V}$ staining positive represent apoptotic event and PI staining positive represent necrotic event. Quadrant 1 (Q1) is the region of necrotic event where annexin V staining negative and PI staining positive. Q2 is late apoptosis event where both annexin V and PI staining positive, Q4 is early apoptosis event with cells stained with annexin $\mathrm{V}$ alone and Q3 represent event of negative staining for both annexin V and PI. Based on the result, there was an increased in the apoptosis event with the increase of goniothalamin concentration. At $50 \mu \mathrm{M}, 53.6 \%$ of the cells are apoptotic, whereas $63.8 \%$ are apoptotic at $61 \mu \mathrm{M}$ treatment and $70.5 \%$ at $100 \mu \mathrm{M}$, respectively. However, etoposide showed only $25.1 \%$ of apoptosis event. Only small percentages of cells were necrotic. Vehicle control or untreated cell was also assessed to ensure the viability of cell for each experiment, majority all the event fall into Q 3 which was $81.9 \%$ of cell stained negative for both stain. Statistical analysis showed significant apoptosis event compare to untreated cells with $\mathrm{p}<0.05$, with no significant difference for necrotic events.

\section{Western blotting}

The involvement of Seladin-1 protein on induction by goniothalamin was assessed using Western blotting (as shown in Figure 4). RT4 cells were treated by $\mathrm{IC}_{50}$ of goniothalamin at 2, 4, 8, 16, and 24 hrs to assess the expression of Seladin-1. The results showed that there was a cleavage of Seladin-1 from $60 \mathrm{kDa}$ to $40 \mathrm{kDa}$, and $20 \mathrm{kDa}$ as increase in treatment time, and the $40 \mathrm{kDa}$ fragment was gradually decreased but not visualized at a later time point. On the contrary, the $20 \mathrm{kDa}$ fragment was gradually increased from 8,16 , and 24 hours.

\section{Discussion}

Goniothalamin induced cytotoxicity and antiproliferative on RT4 cells

Goniothalamin is a styryl lactone derivative that has been proved to have cytotoxic activity and induce apoptosis in a variety of cancer cell lines [28]. However, the cytotoxicity of goniothalamin on urinary bladder cancer has not been assessed before. Therefore, in this study, urinary bladder cancer cell line RT4 was employed to determine the cytotoxicity of goniothalamin on urinary bladder cancer. RT4 cells were treated by goniothalamin $6.25,25,50$, and $100 \mu \mathrm{M}$ for $24 \mathrm{hrs}, 48 \mathrm{hrs}$, and $72 \mathrm{hrs}$. Results showed that $\mathrm{IC}_{50}$ for $24 \mathrm{hrs}$ was $61 \mu \mathrm{M}$; which was higher than previous studies $[23,28]$. Therefore, the treatment time was extended to $48 \mathrm{hrs}$ and $72 \mathrm{hrs;}$ where $\mathrm{IC}_{50}$ for $48 \mathrm{hrs}$ treatment was $38 \mu \mathrm{M}$ and $31 \mu \mathrm{M}$ for 72 hrs respectively. According to previous studies, goniothalamin was able to induce cytotoxic and apoptosis at micro molar concentrations; Chan and coworkers have demonstrated that the $\mathrm{IC}_{50}$ value for $72 \mathrm{hr}$ treatment was $22 \mu \mathrm{M}$ on vascular smooth muscle cells [28]. This result and our findings indicate that goniothalamin is able to induce concentration and time dependent cytotoxic and antiproliferative effects; the effect of which may depend on sensitivity, stage, and type of cancer. An RT4 cell has the characteristic similar to superficial bladder tumor with bearing wild type p53 [29]. According to Al-Sukhun and coworkers, aberration of tumor suppressor gene such as p53 was associated with 

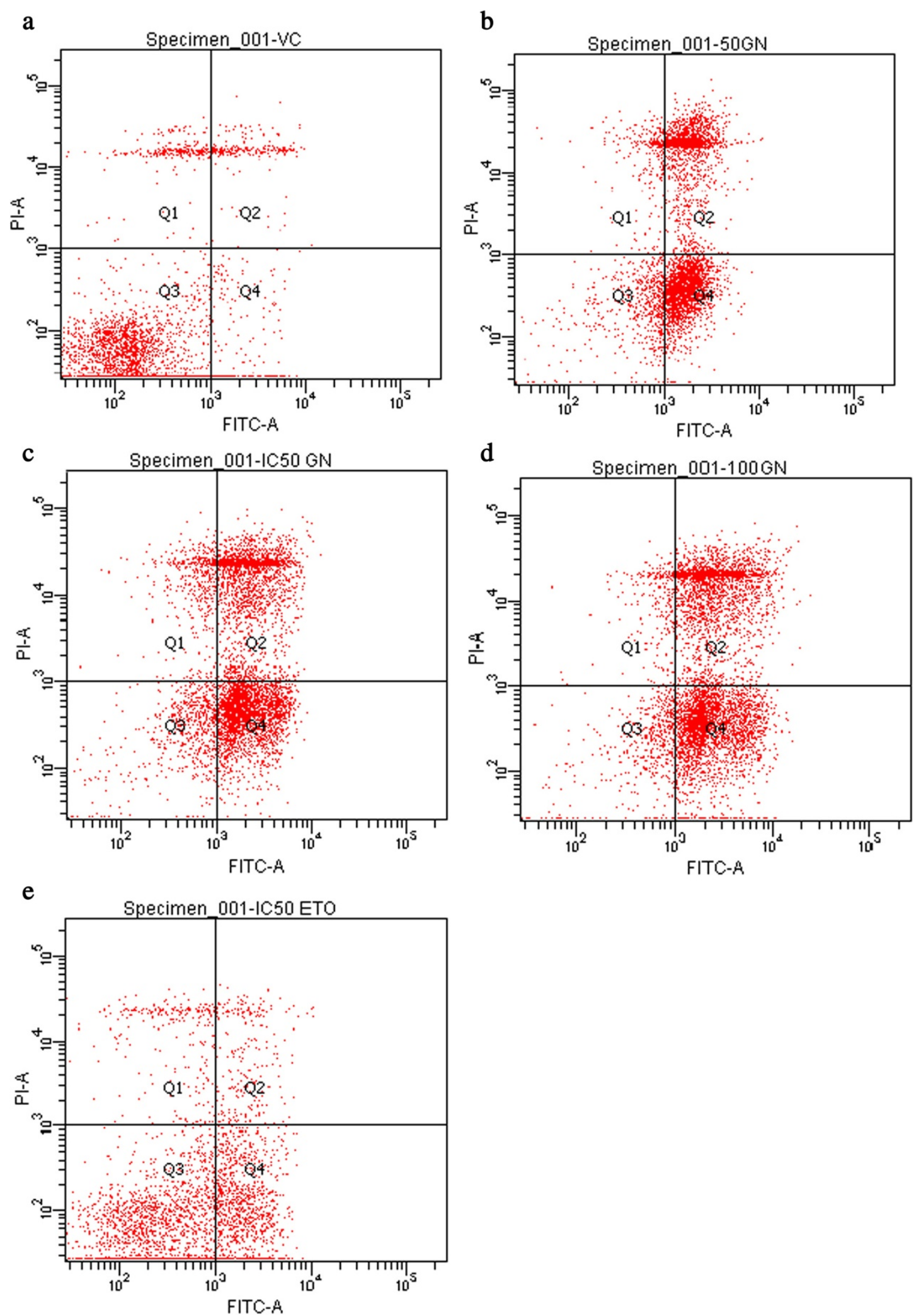

Figure 3 Flow cytometry profile of RT4 cells treated by goniohtalamin (GTN) at 50, $61.3\left(\mathrm{IC}_{50}\right)$, and $100 \mu \mathrm{M}$, etoposide IC 50 for 24 hrs., a) Untreated cells (VC) b) GTN $50 \mu \mathrm{M}$; c) IC 50 GTN d) $100 \mu \mathrm{M}$ GTN and e) etoposide IC $_{50}$. 


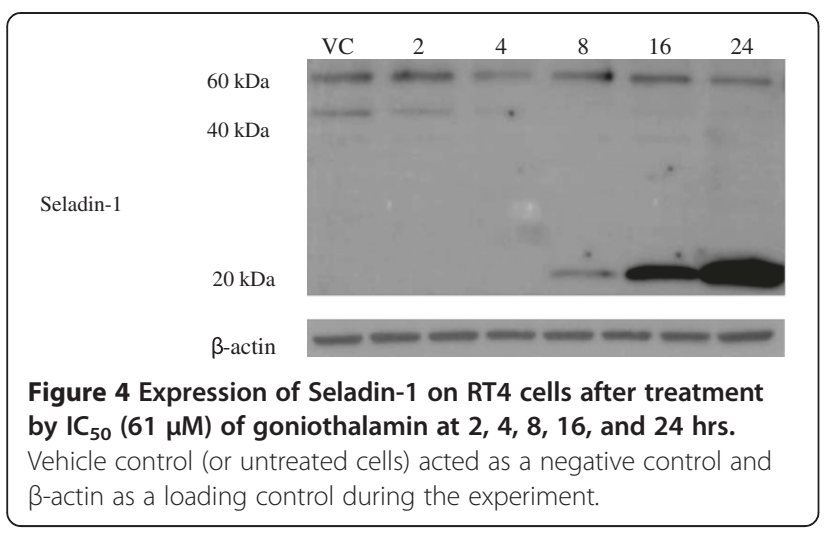

invasive cancer phenotype and influenced the responsiveness of the tumor to chemotherapeutic agents [30]. This may explained the higher $\mathrm{IC}_{50}$ value in this study.

\section{Goniothalamin induced apoptosis on RT4 cells}

Apoptosis was assessed using Annexin V-FITC/PI staining. The assay utilized Annexin $\mathrm{V}$, which is a protein that binds to phosphatidylserine (PS) when cells undergo apoptosis. The externalization of PS was an early event of apoptosis; thus, by using annexin $\mathrm{V}$, conjugated with a fluorochrome (FITC), the event of apoptosis could be quantified by flow cytometer. Based on the results obtained, goniothalamin was able to induce apoptosis on RT4 cells after 24 hrs treatment. Event of apoptosis were concentration dependent, where treatment with $100 \mu \mathrm{M}$ of goniothalamin gave the highest apoptosis event (70.5\%). When comparing $\mathrm{IC}_{50}$ of etoposide, $46 \mu \mathrm{M}$ to $\mathrm{IC}_{50}$ of goniothalamin, events of apoptosis were higher in goniothalamin. This may have been due to different end points of each assay used to detect cell viability and apoptosis, as MTT assay only measured the activation of the mitochondria enzyme [27], while annexin v-FITC labeling was able to detect the flipping of PS on the apoptosis cells [31]. However, in some incidents, the flip-flop of PS may also have occurred as a late event; and in this research, etoposide only acted as a positive control for experiment validation [32]. In addition, necrotic events induced by goniothalamin were less than $10 \%$, which similar to previous studies on various cancer cell lines including cervical cancer, leukemia, vascular smooth muscle cells, and breast cancer cells $[23,25]$.

\section{Involvement of Seladin-1 in goniothalamin induced apoptosis}

Previous studies have shown that styryl lactone compound from Goniothalamus $s p$ was able to induce apoptosis via activation of caspases enzyme cascade, release of cytochrome c, loss of mitochondrial membrane potential, and increase expression of pro-apoptotic $\mathrm{BH} 3$ protein [33]. Therefore, goniothalamin was used in this study as apoptotic inducer to elucidate the role of Seladin-1 in goniothalamin induced apoptosis on human bladder cancer cell line RT4. Upon treatment with goniothalamin, we observed that Seladin-1 was cleaved from $60 \mathrm{kDa}$ to 40 $\mathrm{kDa}$, and $20 \mathrm{kDa}$. As increase in treatment time, the 40 $\mathrm{kDa}$ fragment was undetectable. However, the $20 \mathrm{kDa}$ showed a gradual increased. This result was comparable to previous studies by Greeve and coworker, which showed that upon induction of apoptosis by growth factor deprivation, Seladin- 1 was cleaved by caspase- 3 and caspase 6 to 4 multiple fragments of $20,30,40$, and $50 \mathrm{kDa}$ on human umbilical vein endothelial cells [8]. However, in this study, instead of a $40 \mathrm{kDa}$ fragment, goniothalamin treatment was able to induce a cleavage of Seladin- 1 to 20 $\mathrm{kDa}$ on RT4 cells. This cleavage was believed to be mainly due to the activation of caspase-3. In accordance with previous studies, caspase- 3 was the primary executioner of caspases activated during goniothalamin-induced apoptosis $[17,18,25]$. Therefore, in this study, we are in agreement with Greeve and coworker that Seladin-1 was a caspase- 3 substrate and following the induction of apoptosis by goniothalamin, Seladin-1 was believed to be cleaved and the expression increased; which may resulted in changes of function from anti-apoptotic to pro-apoptotic (as shown in this study). In addition, this evidence also suggested that Seladin-1, which function as antiapoptotic protein, may play a role in the formation of primary bladder cancer. Hence, Seladin-1 can act as a therapeutic target for urinary bladder cancer, or as a screening marker for primary tumors.

\section{Conclusion}

Goniothalamin induced cytotoxicity through apoptosis in human urinary bladder cancer cell line RT4, in concentration and time dependent manner. The involvement of Seladin-1 was observed with increased expression of cleaved fragment $(20 \mathrm{kDa})$ further suggested its role in goniothalamin-induced apoptosis and formation of primary cancer. However, further investigation is needed to elucidate the role of Seladin-1 in urinary bladder cancer.

\section{Competing interests}

The authors declare that they have no competing interests.

\section{Authors' contributions}

NFR Contribution: Participate in the design of study, analysis and interpretation of data; provide important scientific input for result analysis and manuscript preparation. KYH Contribution: Carried out experiment, analysis and interpretation of data, drafted manuscript. ARF Contribution: Carried out experiment, analysis and interpretation of data, drafted manuscript. LBD Contribution: Isolate and provide the studied compound, goniothalamin. VJM-M Contribution: Provide important scientific input for the design of study. KMC Contribution: Participate in the design of study, analysis and interpretation of data; provide important scientific input for result analysis and discussion. SHI-H Contribution: Participate in the design of study, analysis and interpretation of data; provide important scientific input for result analysis and discussion. All authors read and approved the final manuscript. 


\section{Acknowledgement}

This research work was financially supported by the research grant UKM-NN-06FRGS-0143-2010, UKM-DLP-2011-010 and DIP-2012-024. We would like to acknowledge the Center for Research and Instrumentation Management (CRIM), UKM for providing the flow cytometry facility.

\section{Author details}

${ }^{1}$ Biomedical Science Programme, Faculty of Health Sciences, Universiti Kebangsaan Malaysia, Jalan Raja Muda Abdul Aziz, 50300 Kuala Lumpur Malaysia. ${ }^{2}$ Faculty of Science and Technology, Universiti Kebangsaan Malaysia, Bangi 43600, Selangor, Malaysia. ${ }^{3}$ School of Pharmacy and Pharmaceutical Sciences, University of Ulster, Coleraine BT52 1SA, United Kingdom. ${ }^{4}$ Environmental Health and Industrial Safety Science Programme, Faculty of Health Sciences, Universiti Kebangsaan Malaysia, Jalan Raja Muda Abdul Aziz, 50300 Kuala Lumpur, Malaysia. ${ }^{5}$ Toxicology Laboratory, Faculty of Health Sciences, Universiti Kebangsaan Malaysia, Jalan Raja Muda Abdul Aziz, 50300 Kuala Lumpur, Malaysia.

Received: 13 April 2014 Accepted: 15 July 2014

Published: 9 August 2014

\section{References}

1. Tortora GJ, Derrickson B: The Urinary System. In Principle of Anatomy and Physiology. Volume 712. 11th edition. Edited by Roesh B. United States of America: John Wiley \& Sons Inc; 2006:1023-1024.

2. Chester JD, Hall GD, Forster M, Protheroe AS: Systemic chemotherapy for patients with bladder cancer- current controversies and future directions. Cancer Treat Rev 2004, 30:343-358.

3. Chandrasoma P, Clive R: The Ureters, Urinary Bladder \& Urethra. In Taylor: Concise Pathology. 3rd edition. New York: McGraw-Hill Publishing Co; 2001:739-745.

4. de Braud F, Maffezzini M, Vitale V, Bruzzi P, Gatta G, Hendry WF, Sternberg CN: Bladder cancer. Crit Rev Oncol Hematol 2002, 41:89-106.

5. Page BH, Levison VB, Curwen MP: The site of recurrence of non-infiltrating bladder tumours. Br J Urol 1978, 50:237-242.

6. Melicow MM: Tumors of the bladder: a multifaceted problem. J Urol 1974, 112:467-478.

7. Doherty SC, McKeown JA Lopez SR, Walsh IK, McKelvey-Martin VJ: Gene expression in normal urothelium depends on location within the bladder: a possible link to bladder carcinogenesis. J Eur Urol 2006, 50:290-301.

8. Greeve I, Hermans-Borgmeyer I, Brellinger C, Kasper D, Gomez-Isla T: The human DIMINUTO/DWARF1 homolog seladin-1 confers resistance to alzheimer's disease-associated neurodegeneration and oxidative stress. J Neurosci 2000, 20:7345-7352.

9. Waterham HR, Koster J, Romeijn GJ, Hennekam RCM, Vreken P, Andersson HC, FitzPatrick DR, Kelley RI, Wanders RJA: Mutations in the 3b-Hydroxysterol D24-reductase gene cause desmosterolosis, an autosomal recessive disorder of cholesterol biosynthesis. Am J Hum Genet 2001, 69:685-694.

10. Crameri A, Biondi E, Kuehnle K, Lutjohann D, Thelen KM, Perga S, Dotti CG, Nitsch RM, Ledesma MD, Mohajeri MH: The role of seladin-1/DHCR24 in cholesterol biosynthesis, APP processing and $A \beta$ generation in vivo. EMBO J 2006, 25:432-443.

11. Sarkar D, Imai T, Kambe F, Shibata A, Ohmori S, Siddiq A, Hayasaka S, Funahashi H, Seo H, The Human Homolog of Diminuto/Dwarf1 Gene (hDiminuto): A novel ACTH-responsive gene overexpressed in benign cortisol-producing adrenocortical adenomas. J Clin Endocrinol Metab 2001, 86:5130-5137.

12. Luciani $P$, Gelmini S, Ferrante E, Lania A, Benvenuti S, Baglioni S, Mantovani G, Cellai I, Ammannati F, Spada A, Serio M, Peri A: Expression of the antiapoptotic gene seladin-1 and octreotide-induced apoptosis in growth hormone- secreting and nonfunctioning pituitary adenomas. J Clin Endocrinol Metab 2005, 90(11):6156-6161.

13. Bonaccorsi L, Luciani P, Nesi G, Mannucci E, Deledda C, Dichiara F, Paglierani M, Rosat F, Masieri L, Serni S, Carini M, Proietti-Pannunzi L, Monti S, Forti G, Danza G, Serio M, Peri A: Androgen receptor regulation of the seladin-1/ DHCR24 gene: altered expression in prostate cancer. Lab Investig 2008, 88:1049-1056.

14. Stasi D, Vallacchi V, Campi V, Ranzani T, Daniotti M: DHCR24 gene expression is upregulated in melanoma metastases and associated to resistance to oxidative stress-induced apoptosis. Institute J Cancer 2005, 115:224-230.
15. Wu C, Miloslavvskaya I, Demontis S, Maestro R, Galaktionov K: Regulation of cellular response to oncogenic and oxidative stress by sealdin-1. Nature 2004, 432:640-645.

16. Khuda II-E, Koide N, Noman ASM, Dagvadorj J, Tumurkhuu G, Naiki Y, Ti K, Ti Y, Ti Y: Seladin-1 is a novel lipopolysaccharide (LPS)-responsive gene and inhibits the tumour necrosis factor-a production and osteoclast formation in response to LPS. Immunol J Cells Mo/ System Technol 2010, 131:59-66.

17. Inayat-Hussain SH, Osman AB, Din LB, Ali AM, Snowden RT, MacFarlane M, Cain $\mathrm{K}$ : Caspases-3 and -7 are activated in goniothalamin-induced apoptosis in human Jurkat T-cells. FEBS Lett 1999, 456:379-383.

18. Inayat-Hussain SH, Annuar BO, Din LB, Ali AM, Ross D: Loss of mitochondrial transmembrane potential and caspase- 9 activation during apoptosis induced by the novel styryl-lactone goniothalamin in HL-60 leukemia cells. Toxicol Vitro 2003, 17:433-439.

19. Ali AM, Mackeen HM, Aun QB, Zauyah Y, Azimahtol HL, Kawazu K: Cytotoxicity and electron microscopy of cell death induced by goniothalamin. Planta Med 1997, 63:81-83.

20. Pihie AH, Stanslas J, Din LB: Non-steroid receptor-mediated antiproliferative activity of styrylpyrone derivative in human breast cancer cell lines. Anticancer Res 1998, 18:1739-1743.

21. Rajab NF, Hamid ZA, Hassan H, Ali MA, Din LB, Inayat-Hussain SH: Evaluation of the cytotoxic and genotoxic effects of goniothalamin in leukemic cell lines. Environm Mutagen Res 2005, 27:161-164

22. Chen WY, Wu CC, Lan YH, Chang FR, Teng CM, Wu YC: Goniothalamin induces cell cycle-specific apoptosis by modulating the redox status in MDA- MB-231 cells. Eur J Pharmacol 2005, 522:20.

23. de fa Tima A, Kohn LK, Ernesto de Carvalhob J, Pilli RA: Cytotoxic activity of (S)-goniothalamin and analogues against human cancer cells. Bioorg Med Chem 2006, 14:622-631.

24. Vendramini-Costa DB, Daltro de Castro IB, Tasca Góis Ruiz AL, Marquissolo C, Pilli RA, de Carvalho JE: Effect of goniothalamin on the development of Ehrlich solid tumor in mice. Bioorg Med Chem 2010, 18:6742-6747.

25. Chan KM, Rajab NF, Siegel D, Din LB, Ross D, Inayat-Hussain SH: Goniothalamin induces coronary artery smooth muscle cells apoptosis: the p53-dependent caspase-2 activation pathway. Toxicol Sci 2010, 116(2):533-548.

26. Jewers K, Davis JR, Dougan J, Machanda AH, Blunden G, Kyi A, Wetchapinan S: Goniothalamin and its distribution in four goniothalamus species. Phytochemistry 1972, 11:2025-2030.

27. Mosmann T: Rapid colorimetric assay for cellular growth and survival: application to proliferation and cytotoxicity assays. J Immunol Meth 1983, 65:55-63.

28. Chan KM, Rajab NF, Ishak MHA, Ali AM, Yusoff K, Din LB, Inayat-Hussain SH: Goniothalamin induces apoptosis in vascular smooth muscle cells. Chem Biol Interact 2006, 159(2):129-140.

29. Chresta CM, Masters JRW, Hickman JA: Hypersensitivity of human testicular tumors to etoposide-induced apoptosis is associated with functional p53 and a high Bax: Bcl-2 ratio. Cancer Res 1996, 56:1834-1841.

30. Al-Sukhun S, Hussain M: Current understanding of the biology of advanced bladder cancer. Cancer 2003, 97(8):2064-2075.

31. Fadok VA, Bratton DL, Frasch SC, Warner ML, Henson PM: The role of phosphatidylserine in recognition of apoptotic cells by phagocytes. Cell Death Differ 1998, 5:551-562

32. Denecker G, Dooms H, VL G, Vercammen D, Grooten J, Fiers W, Declercq W, Vandenabeele $P$ : Phosphatidyl serine exposure during apoptosis precedes release of cytochrome $c$ and decrease in mitochondrial transmembrane potential. FEBS Lett 2000, 465(1):47-52. 7.

33. Wiart C, Goniothalamus Species: A source of drugs for the treatment of cancers and bacterial infections? Evidence-Based Compl Alternat Med 2007 4(3):299-311.

doi:10.1186/1472-6882-14-295

Cite this article as: Yen et al:: Involvement of Seladin-1 in goniothalamininduced apoptosis in urinary bladder cancer cells. BMC Complementary and Alternative Medicine 2014 14:295. 